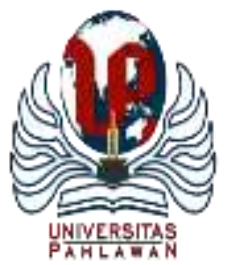

Edukatif : Jurnal Ilmu Pendidikan Volume 3 Nomor 6 Tahun 2021 Halm 4014 - 4024

EDUKATIF: JURNAL ILMU PENDIDIKAN

Research \& Learning in Education

https:/ledukatif.org/index.php/edukatif/index

\title{
Students' Perception toward English Speaking Motivation during Online Learning System through Multimodal Approach
}

\author{
Usman Sidabutar ${ }^{凶}$ \\ Universitas HKBP Nommensen Medan, Indonesia \\ E-mail : usman.sidabutar@uhn.ac.id
}

\begin{abstract}
Abstrak
Pendidikan di era 4.0 ini ditekankan untuk menumbuhkan cara membuat proses belajar-mengajar lebih praktis dan innovative dan mampu menyesuaikan kebutuhan sosial dan lingkungan. Penelitian ini bertujuan untuk menemukan persepsi mahasiswa terhadap pengajaran melalui pendekatan multimodal yang difokuskan untuk teks verbal dan teks visual. Subjek penilitian ini adalah mahasiswa group C semester enam di Pendidikan Bahasa Inggris Universitas HKBP Nommensen Medan. Penelitian ini dilakukan dengan menggunakan Eksperimen dan kuisioner melalui pendekatan multimodal dan dilanjutkan dengan. Pelaksanaan pengajaran dengan pendekatan multimodal yang terfokus pada verbal dan visual cenderung mendorong minat siswa dalam berbicara bahasa Inggris. berdasarkan persentase yang di lihat bahwa pencapaian siswa melalui pendekatan multimodal adalah 73,33 persen dan sangat relevan dengan motivasi belajar siswa sebesar 86,67 persen dengan rerata nilai tes 76,73 . Ini adalah salah satu bukti yang menunjukkan bahwa kreativitas dosen dengan pengajaran melalui pendekatan multimodal yang dipadukan melalui digital berperan untuk memacu minat siswa untuk berbicara bahasa inggris terhadapa mata kuliah yang akan diajarkan.
\end{abstract}

Kata Kunci: pendekatan multimodal, pembelajaran online, kemampuan berbicara bahasa Inggris

\section{Abstract}

Education is emphasized to grow the tools offered by the 4.0 to create the teaching-learning process more practical and adapted to the social demands. This research aims at finding the students' perception of the teaching method by a multimodal approach which is focused on the construction of verbal texts and visual texts. The subject of this research is the students of the sixth semester in the English Department of the HKBP Nommensen University Medan. This experiment research is applied by the multimodal approach which is focused on the construction of verbal texts and visual texts and continued by questionnaires. The implementation of teaching with a multimodal approach which is focused on verbal and visual tends to motivate students' interest in speaking English. The result of the score achieved by the students with 73.33 percent is relevant to the students' motivation with 86.67 percent by the mean of test score in 76.73 . This is the one of evidence that shows the creativity of the lecturer by multimodal approach by which the digital play makes a huge manner in the interesting subject to be lectured.

Keywords: multimodal approach, online learning, English speaking skills

Copyright (c) 2021 Usman Sidabutar

$\triangle$ Corresponding author:

Email : usman.sidabutar@uhn.ac.id

DOI : https://doi.org/10.31004/edukatif.v3i6.1390

ISSN 2656-8063 (Media Cetak)

ISSN 2656-8071 (Media Online)

Edukatif : Jurnal Ilmu Pendidikan Vol 3 No 6 Tahun 2021 p-ISSN 2656-8063 e-ISSN 2656-8071 
4015 Students' Perception toward English Speaking Motivation during Online Learning System through Multimodal Approach - Usman Sidabutar

DOI: https://doi.org/10.31004/edukatif.v3i6.1390

\section{INTRODUCTION}

In global platforms, teaching methods and approaches are commonly engaged to the new modern system in which is focused on the written language and other modes of communication (image, music, etc.) to have played a minor role in the teaching-learning process (Martínez Lirola, 2020; Putriani, 2021). In this sense, the direct teaching approach conventionally applied is limited space for movement. Education is emphasized to grow the tools offered by the 4.0, students can contribute to making the teaching-learning process more practical and adapted to the social demands.

Cultural context, English mastery, ICT-based pedagogy, and successfully real use of communication, English teaching and learning process in Indonesia should be assisted by multimodal resources (Yusriati \& Hasibuan, 2019). It is similar to Panyajamorn et al. (2018) who said that is the expectation that intelligent learning between teachers, understudies, and learning assets will lead understudies to a superior course It points out that the multimodal approach is improving the effectiveness of e-learning for different kinds of students, subjects, and areas. In any case, in all actuality, learning in Indonesia sticks to the old worldview, where understudies acquire information by being given or instructed by individuals who are viewed as more intelligent, for example, educators who offer data to understudies, dynamic educator plans while standoffish understudies, teachers who give subject while understudies simply get it. In concern to the educational problem in the global platform, Alqahtani \& Rajkhan, 2020; Nashir \& Laili (2021) had investigated that the technology is in an educational institution is the readiness of E-learning execution played a large role in boosting the educational process during the COVID-19 pandemic. By then instructors know while understudies don't have even the remotest clue, this is at this point being practiced in learning in the issue encountered in Indonesia and the world.

According to Adijaya (2018), the environment is the mode of information as the way humans exchange the brain to perception, hearing, smells to develop their interaction and boost the learning environment atmosphere among class members what is called the sense of channel.

The multimodal approach is the orientation for the channel process during learning and teaching in the classroom. The qualities of learning in schools actually which use the traditional models and in the execution of learning are as yet overwhelmed by the part of teachers, so the understudy-focused learning approach isn't completely coordinated in learning in grade school. That is the thing that at last affects not exactly ideal learning measures. It is demonstrated by the low capacity of understudies to investigate information freely by education. That is one of the learning developments. This is because multimodal proficiency is thought in learning improvement exercises in a learning climate that is viewed as a matter of advancement in the prevention to this problem, Song (2018) suggested that serving teaching by the application of multimodality with arise of PowerPoint slides, video, etc have practical significances for students speaking ability.

Speaking is categorized as a prolific skill that everyone can build meaning based on the circumstances (Suryana et al. 2020). The sound and the visual aids are the relevant way to motivate people to speak. Proficiency in speaking English has become a requirement for academics starting at the primary, secondary, and higher education levels. However, it is not easy for students to communicate in English quickly. According to Nunan in Tampubolon Sahlan et al. (2018), speaking skill is utterances that have meaning that a person produces systematically in verbal form. Each person can say an infinite number of words each day depending on the individual. Just as Fulcher in Tampubolon sahlan et al. (2018), speaking is what someone says to another person or a listener which is conveyed verbally. A person's speaking skills are characterized by the meaning and pronunciation that others hear so that good communication can be realized. This statement is also related to the article that had been published in an international journal that discussed the effect of the English laboratory on speaking achievement. 
Teaching and learning by multimodal modal approach applied to dialogue has created the wider and potential application in mobile interaction and modified the traditional technique for the efficiency and integrity of information expression to be superior (Yang \& Tao, 2019). Combining multimodal perfectives and digital modes provide a meaningful picture of students learning, the design process shows the evidence for affordance and potential relevance for practice (Fjørtoft, 2020). English teachers having quite high multimodal levels enhance the successful implementation of a rich learning environment for their students.

Based on the fact and gap of the research, the problem of the research brings up the students' perception of the teaching method by the multimodal approach which is focused on the construction of verbal texts and visual texts found on the lecturer's material during a class meeting. The main linguistic elements that reveal and give essence to the meaning of a picture message the lecturer material are Announcement, Enhancer, Emblem, and Call-and Tag.-visit information. It is discovered in the answer of English students of the sixth semester toward the questions or statement by lecturer having conducted the multimodal approach during the online learning process, (Fang, 2015). Teaching through a multimodal approach is a method that has increasingly proven its competence in the academic world and even in other fields of work professionally. Moreover, this method is unlimited space in the era of digital education because this multimodal approach enables teachers to grow a very large impact strategy on the acquisition of English as a foreign language. The multimodal approach has transformed the traditional learning system into a modern one so that the acquisition of English, especially conversation, will be more flexible and fast. Wet the habits of students with this approach will be systematic according to the needs of students to internalize language information.

Furthermore, several studies have found that multimodal-based learning can improve communication competence in students. The systemic approaches to teaching visual texts emphasize the explicit teaching of the common features of visual text and introduce a common multimodal approach used to engage learners, (Firmansyah, 2018; Twiner et al., 2021) Implementation of technology through the application of the software is connected to multimodal approach creates students to be more respectful and achieve more results (Sewell \& Denton, 2011). Yusnimar et al. (2020) figured out the multimodal analysis in developing EFL students' ESP listening skills in civil engineering. The use of pictures and dynamic pictures in the video aid the students to understand the meaning of the words they heard. The fifth, the previous research is Lee (2014) who analyzed the students of Chinese speaking EFL through an arts-integrated multimodal approach to promote English learning. The multimodal approach enhanced the students' motivation and confidence after they have been discouraged by conventional language learning instructions. The achievement of Chinese learners after applying the multimodal approach emerges the significant impact on their writing task.

The multimodal approach is characterized by the nature of modern society demand (Martínez Lirola, 2020). Pratiwi (2021) found in the research that using the Picture and Picture learning model can influence in improving students' creative thinking skills in elementary school in science learning because the use of learning models makes variations in class so students are more enthusiastic in learning. The roles contained in the multimodal approach such as pictures, videos, and visual integration with words, sentences, and sentences have a very significant role in the meaning of communication. Images, text, diagrams contained in a multimodal approach provide a difference in the mode of communication (Westberg, 2021). The multimodal approach has different semiotics and meanings when used in code and context (Baldry Paul, J., 2008). The trend of a multimodal application contained in books, digital devices that can be used to carry out these methods when they apply them in the world of work or the realm. Therefore, training on a multimodal approach that is applied with digital devices is very much needed in this modern digital era.

The development of pedagogies and teaching English speaking by multimodal approach refers to the paradigm revolution for the useful, effective, and relevant to students' needs and interests (Laadem \& Mallahi, 2020). This is appropriately applied by organizing and developing ideas. The multimodal approach advocates the source of creativity and modernity for teachers and students. The multimodal approach is believed to be 
4017 Students' Perception toward English Speaking Motivation during Online Learning System through Multimodal Approach - Usman Sidabutar

DOI: https://doi.org/10.31004/edukatif.v3i6.1390

beneficial to English language learners with limited English. It can help them engage in multiple reading and writing activities, in other words, shifting modes from visual to verbal or vice versa help the students to have better understand, appreciate, and interpret the complex concept in English, (Firmansyah, 2018; Julinar, 2019; Lim, 2018)

Multimodal movement and the relationships between multimodality and speaking and writing connections are provided in the teaching-learning process, (Kang, 2020). Multimodal interaction technologies, such as computer vision and embodied conversational agents, have recently been investigated for the training and assessment of interpersonal skills by the extracted features, measures of public speaking anxiety and personality, annotations of participants' behaviors, and expert ratings of behavioral aspects and overall performance of the presenters (Sullivan, 2018). Through the multimodal discourse analysis software, students can study the pronunciation, intonation, expression changes, and body movements of the teacher's teaching in micro-class, to assist learning according to these characteristics (Xing, 2019).

Teaching through a multimodal approach, technology, and combination through the use of music is a must for a middle school teacher and a college teacher for the achievement of quality learning and teaching (Sewell \& Denton, 2011). It is similar to Ruiz-Madrid \& Valeiras-Jurado (2020) who said that the teaching and learning of multimodal competence in oral genres in general, and in oral emergent genres in particular, is a crucial component of the curriculum in ESP and EAP courses. Furthermore, by embracing multimodal meaning-making and incorporating it as valuable learning in language subjects, students and teachers could access and assess students' complete and widened literacy competencies, instead of focusing on some practices, while largely ignoring others (Magnusson \& Godhe, 2019). According to Reyes-Torres \& Raga (2020), teaching by using a multimodal approach that allows students to develop key aspects of literacy, reflect individually or in groups on the different elements that the text presents, and, ultimately, think critically and convey their ideas. In this case, the multimodal approach has a great effect on students' reflection toward constructing meaning at the time of speaking. This is indicated by the teacher's recognition to engage the students in teaching meaning-making as the way to gain their vocabulary while speaking English. The implementation of the multimodal approach is the way of teachers' approach on the internet utility, designs of video, pictures, sounds, and the role of student's perception for speaking creativity. Applying multimodal is certainly striving teacher's benefit as the teacher can divert the method for teaching speaking specifically through enhancing content, clearly explaining the real context of the subject and improving the progress of students' cognition for speaking effectively.

Optimizing multimodal approach in learning creates the prompt opportunity for students to be creative for thinking, (Hidayah et al., 2019). Furthermore, students will be able to facilitate their neurolinguistics' capacity to practice their English ability as they acquired in the last learning. Moreover, a visual and verbal relationship can be categorized as projection-locution. Interpersonally, it is shown that images can play an essential role in shaping readers' feelings or attitudes through cartoon characters, color, natural coding orientation, and typeface. Together with the verbal mode, images play a role in positioning the readers' interaction with the textbook, (Jauhara et al., 2018). Further, the exciting remainder of this paper focuses on multimodal approach is organized to verbal as an announcement, enhancer, emblem, and call-and-tag.-visit information. The visual in multimodal modal is organized to Lead: Locus of Attention (LoA), Complement to the Locus of Attention (Comp. LoA). The resulting theoretical framework will be closer to a standard analysis of verbal and visual to prove the interesting method of teaching English speaking by an online learning system.

\section{METHOD}

This qualitative research focused on the 30 students as the informant to find the results of data by whom taking the subject of Cross Culture Understanding taught in the sixth semester in English Department of 

Multimodal Approach - Usman Sidabutar

DOI: https://doi.org/10.31004/edukatif.v3i6.1390

HKBP Nommensen University. The location of this research will be conducted in virtual face-to-face by google meet. The time of this research is taken within seven meetings which were conducted from April 2021 to June 2021. The researcher chose this location because the target of data was very accurate in online learning system. The focus of this research was to obtain the students' perception of English Speaking motivation with an online learning system through a multimodal approach. To find the pure data, the researcher handled the class of Cross Culture Understanding in which the subject is mostly taken into the theoretical method within along sentences. To facilitate this subject, the researcher delivered the material using a laptop that had been designed in the PowerPoint and then, configuring it onto the application of the Screen Cast O Matic. Presenting pre-designed images or videos with keywords or phrases and clauses related to the topic being discussed the theme of culture which contains a variety of meanings. The researcher applied this multimodal approach in a combined verbal and visual. Furthermore, the lecturer who is a researcher makes a creative video that contains a person's character speaking according to their respective cultures. The video movements and variations of the pictures contained in the PowerPoint with a distinctive visual and verbal combination encourage students to speak by asking opinions regarding the topic discussed. After conducting class meetings, the researcher shared the questions regarding Digitalization for online learning, Students' motivation and interest, and Students' English speaking achievement. To convince the students' statements, the researcher conducted three times of speaking test by giving topics shared by using Multimodal Approach with verbal and visual. The researcher gave the point for students who give opinions English regarding the topic within one minute for each student. The three steps of the test become the procedure to get the pure data.

\section{RESULTS AND DISCUSSIONS}

To find out the assessment of students who are members of the Cross Culture Understanding course which is guided in English lessons in the eighth semester, it is found that students can communicate in English. Their assessment of multimodal applied to learn in the Cross Culture understanding course has a side effect on proficiency in speaking English. The side effects of this study are introduced in the attached section. All students who were visited as research subjects reacted firmly to the question because they assume that multimodal teaching works with learning. The fundamental reason that is played is to support the quality and acceleration of learning during the pandemic and preparation for learning that will be faced in the era of digitalization it is easier to learn and explore other sciences with multimodal tools.

Based on the table above, the students' positive perception. Lecturers can carry out the teaching and learning process by applying the theory and the practice of multimodal in the online learning system during the Covid-19 pandemic situation. Some of them stated that the teaching and learning process carried out at home through the online learning system was quite good. They argue that this multimodal is arguably quite effective because it is a method the only way out to continue learning online during the Covid-19 pandemic is still going on in Indonesia, so they can still learn even if they do not directly at school. The teaching and learning process through an online learning system has many things advantages, such as students can be more independent to learn so they do not depend on the teacher, time and place to study too flexible anytime and anywhere, but in, this context they have to stay on homes due to government regulations during the pandemic.

Based on the result of the lecturer questionnaires for the statement 1 until 10, the students choose strongly and strongly agree. The students' perception of the multimodal approach is positive. Some of them stated that the teaching and learning process carried out at home through the online learning system was quite good. They argue that this method is arguably quite effective because it is a method the only way out to continue learning online during the Covid-19 pandemic is still going on in Indonesia, so they can still learn even if they don't directly at school. The teaching and learning process through applying the theory and the practice of multimodal in the online learning system has many things advantages, such as students can be 
4019 Students' Perception toward English Speaking Motivation during Online Learning System through Multimodal Approach - Usman Sidabutar

DOI: https://doi.org/10.31004/edukatif.v3i6.1390

more independent to learn, prevent the boredom of students, and gain the students to be motivated to apply in the teaching practice ahead.

Based on the results of students' questionnaires, there are $73.33 \%$ of students strongly agree, $20 \%$ of students agree, $6.67 \%$ disagree, with the first statement. It showed that the respondents chose the question to agree as to the most answers because the process of teaching-learning by multimodal approach is easier to understand and prevents boredom while learning the subject. For the second statement, there are $60 \%$ of students strongly agree, $30 \%$ agree, and $10 \%$ disagree with the second statement. In concern to the respondents' question on the second results which conclude the students' tendency to strongly agree of learning activity by multimodal approach combined with screencast o Matic application. The multimodal approach stimulates students' passion not to be monosyllables but to turn them into talk active. For the third statement it can be seen that there are $67 \%$ of students were strongly agree, and $30 \%$ of students agree and no students disagreed. Studying cross-culture understanding by the multimodal approach is not only stimulating theory comprehension but also modifies students to fluently speak multimodal. A multimodal approach designed with visual can affect student English skill as writing and listening. Students either responded that multimodal approach can foster students' independent learning attitudes.

The fourth statement is the contribution of digital application with multimodal approach provides an easier part to social competencies. Students can access the screencast o Matic's mobile phone or laptop. This can infer that everyone can learn to speak English faster than ever. From the results of the student's answers to the questionnaire above, it can be seen that there are $86.67 \%$ of students strongly agree, $10 \%$ students agree,3.33\% disagree. The fifth question was proposed to the using of digitally based on PowerPoint during teaching and presentation. The students ensure that they get to benefit from the multimodal approach toward other activities for instance teaching an English course during a pandemic is not only teaching in the classroom but also paying a mode in the youtube channel. This evidence regarding statement there is $66.67 \%$ strongly agree, $23.33 \%$ agree, and $10 \%$ disagree and 9 strongly disagree strongly fifth statement. The results of the students questionnaire above in the sixth statement, it can be seen that there are $76.67 \%$ students strongly agree, 16.67 students agree, 6.66 disagree, So it can be concluded that the respondents chose to agree as to the most answers for the statement that online teaching-learning process can foster students the motivation in teaching lead teaching-learning.

The results of the seventh question show that the multimodal approach is varied as can summarize many chapters with a sort of time digitized by PowerPoint PowerPoint. The role of linguistics can move forward the conventional teaching tradition by the society within. It can be seen that there are $56.67 \%$ of students only agree, $33.33 . \%$ students agree, $10 \%$ students have disagreed concluded that the respondents chose to agree as to the most answers for the statement that online teaching-learning is easy to facilities students in gathering assignments.

One might be conducted by the students regarding the eighth question. The result of students toward the fourth question showed that there are $73.33 \%$ of students were strongly agreestrongly $4 . \%$ students across ee, and 3.33 disagreed with the statement. The students were strongly agreed can imply the application of multimodal at the approach bring up the impact on their English speaking ability. Furthermore, this will also highlight the role of multimodal approach based on the content in the digital enhances their English quality.

From the ninth statement that there are $60 \%$ of students strongly agree, $26.67 \%$ students of agreeing and $13.33 \%$ disagree toward achievement. So it can be concluded that the respondents chose to agree as to the most answers for the statement infer that multimodal approach can guarantee to teach quality in the process of transferring ideas, knowledge of any subjects course especially English speaking. From the results of the student's student selected to the tenth question is the content of images or videos attached with varieties of words can enhance the students' vocabulary, pronunciation to speaking and listening ability. it can be seen that 
4020 Students' Perception toward English Speaking Motivation during Online Learning System through Multimodal Approach - Usman Sidabutar

DOI: https://doi.org/10.31004/edukatif.v3i6.1390

there are $70 \%$ of students strongly agree, $23.33 \%$ of students agree, and $6.67 \%$ disagree. Thus, this last question recommends teachers and students applying the multimodal approach in the digital era.

Overall, the comparisons of the surveys indicated to the questions were satisfying. The above responses could be summarized as indicated in the following table.

Table 1

The Percentage of Students' Perception in Multimodal Approach

\begin{tabular}{llllll}
\hline No & Factor & Question & $\begin{array}{l}\text { Strongly } \\
\text { Agree }\end{array}$ & Agree & Disagree \\
\hline 1 & Digitalization & 1 & 73.33 & 20 & 6.67 \\
& for online & 2 & 60 & 30 & 10 \\
\multirow{2}{*}{2} & learning & 3 & 67 & 33 & 0 \\
& Students & 4 & 86.67 & 10 & 3.33 \\
& motivation & 5 & 66.67 & 23.33 & 10 \\
& and interest & 6 & 76.67 & 16.6 & 6.6 \\
& Students & 7 & 56.67 & 33.33 & 10 \\
& English & 8 & 73.33 & 23.34 & 3.33 \\
& speaking & 9 & 60 & 26.67 & 13.33 \\
& achievement & 10 & 70 & 23.33 & 6.67 \\
\hline
\end{tabular}

The survey results above as the overall percentage of respondents who rated the experiment in teaching through multimodal approach as "strongly agree" with $86 \%$ involved the fourth questions. It was surprising to see the percentage of strongly agree and agree to refer to the students' satisfaction was achieved. The comparison of the results indicated in the table shows that digitalization in multimodal approach for online learning enables students to achieve English speaking were arisen with highly motivated and interested in.

In terms of students' feedback on their achievement having experimented, the table in the following includes the score of students in speaking English were rated.

Table 2

The Students' Score in Speaking English after Experimental

\begin{tabular}{lllll}
\hline No & $\begin{array}{l}\text { Students' } \\
\text { Initial }\end{array}$ & Test $\mathbf{1}$ & Test 2 & Test 3 \\
\hline 1 & BR & 73 & 78 & 76 \\
2 & EP & 80 & 82 & 80 \\
3 & PM & 65 & 66 & 60 \\
4 & BO & 74 & 78 & 73 \\
5 & FP & 68 & 65 & 67 \\
6 & OG & 84 & 83 & 85 \\
7 & CH & 80 & 82 & 84 \\
8 & AS & 75 & 70 & 73 \\
9 & WS & 73 & 71 & 76 \\
10 & RK & 57 & 55 & 53 \\
11 & LS & 67 & 65 & 61 \\
12 & PS & 76 & 75 & 78 \\
13 & AZ & 84 & 85 & 83 \\
14 & AS & 85 & 83 & 86 \\
15 & LM & 76 & 72 & 77 \\
16 & EM & 68 & 69 & 72 \\
17 & DS & 72 & 74 & 78 \\
18 & RI & 78 & 77 & 80 \\
19 & MS & 73 & 70 & 76 \\
20 & WB & 77 & 80 & 83 \\
21 & NS & 86 & 84 & 85 \\
22 & DB & 81 & 82 & 84
\end{tabular}


4021 Students' Perception toward English Speaking Motivation during Online Learning System through Multimodal Approach - Usman Sidabutar

DOI: https://doi.org/10.31004/edukatif.v3i6.1390

\begin{tabular}{lllll}
\hline No & $\begin{array}{l}\text { Students' } \\
\text { Initial }\end{array}$ & Test 1 & Test 2 & Test 3 \\
\hline 23 & SS & 70 & 72 & 77 \\
24 & NS & 69 & 70 & 73 \\
25 & RS & 76 & 75 & 78 \\
26 & CM & 77 & 78 & 79 \\
27 & SP & 74 & 76 & 75 \\
28 & AS & 81 & 85 & 87 \\
29 & SS & 80 & 84 & 83 \\
30 & FL & 76 & 79 & 80 \\
& & & & \\
\hline Total & & $\mathbf{2 2 5 5}$ & $\mathbf{2 2 6 5}$ & $\mathbf{2 3 0 2}$ \\
( $\sum$ ) & & & & \\
\hline Mean & & $\mathbf{7 7 5 . 1 6}$ & $\mathbf{7 5 . 5 0}$ & $\mathbf{7 6 . 7 3}$ \\
\hline
\end{tabular}

The enrolled respondents to this survey were 30 students. The scoring average of the first test is 75 around; following to the second is 75,50 , and then the third test score is getting higher within 76.73 . This indicates that the Experiments to multimodal approach in the course of English subject were growing better and achieve the result. Having done the test survey, the student's scores were improving better compared to the previous score. The ultimate survey was that 90 percent around have been able to speak English better and guided themselves into the leadership of education. Another assumption indicates that the scoring average is the teaching and learning in multimodal approach is reasonably projected to digitalization.

Based on the results of the study, it was found that Acquiring English, especially in speaking, must be colored by innovative learning. The conventional language learning tradition such as face-to-face guided by books has often been carried out with not yet great results. Especially with the demands of modern times being challenged by globalization, digital has become a tool for teachers and students to use as a variety of teaching and learning English speaking. This is inseparable from the support of experts who state that innovation has presented new instruments that we use to think; subsequently, the manners by which we think would likewise change (Sankey, 2006). The same is described by Martínez Lirola, (2020), one of the key features of the twenty-first century is the multimodal nature of modern societies. Humans will be required to face the developments of this modern era as well as the demands of educational development.

The implementation of teaching with a multimodal approach that has taken place in the cross-culture understanding class in semester 6 has contributed to the development and acceleration of English language acquisition, especially in speaking. Not only in speaking, but it will have an impact on knowledge skills that are relevant to their chosen professional goals as well as being a competent teacher. It is true that Likewise, the use of the multimodal approach permits understudies to exploit education outside of school and assists them with getting more capable in proficiency (Sewell \& Denton, 2011). Someone's interest in learning English speaking finally moved forward. Students become active in speaking and get new ideas with the emergence of a multimodal approach. It can be concluded that by looking at pictures and videos, a person can tell the contents of the images or videos seen in their first language. This is the driving demand for speaking English, especially supported by the combination of words, phrases, and sentences in the image.

Students who are respondents in this article have stated with honesty that the multimodal approach guarantees real, innovative, and quality learning. The difficulties they have imagined will be helped by the use of a multimodal approach. Of course, what Baldry Paul, J. (2008) said that the multimodal approach is characterized as a structure that requires aggregate translation of at least two writings, visuals, recordings, designs, liveliness, sound, music, developments and looks to create an implying that will make it simpler for understudies to get information. Finally, one of the most exciting toward the students' statements regarding multimodal approach is the combination of verbal components as Announcement, Enhancer, Emblem and 
4022 Students' Perception toward English Speaking Motivation during Online Learning System through Multimodal Approach - Usman Sidabutar

DOI: https://doi.org/10.31004/edukatif.v3i6.1390

Call-and Tag.-visit information with the visual of the verbal and visual component as Lead: Locus of Attention (LoA), Complement to the Locus of Attention (Comp. LoA). This should lead us to explore the method-logical constraints and possibilities of doing so in future research.

\section{CONCLUSION}

It has recently been explored how the practice of the multimodal approach in online Learning of English speaking at the university level has become a necessity to face the world stage. The digital takes a great exciting part on verbal and visual on the lecturer's material to learn a practical and a very easy method on English speaking. Verbal and visual by multimodal approach is a very targeted method where teachers can use digital parts such as applying emblem, announcement, and enhancer in a short statement by presentations, videos, and animations. This application becomes an introduction method to students' cognitive assumption on digital manner to learn speaking English rapidly. After we discussed the multimodal approach, the case of conventional system in giving argument or interaction is a system making a lack ability if is applied in online learning system. The future human-digital dialog is a demand to motivate students to speak and to awake their ability. The practice of implementing the multimodal approach found in visual and verbal invites to guide the opportunities for teachers and students in the digital era to learn how to make material to be taught with great creativity. Finally, some practical examples of multimodal approach are presented and possible methods to build skills to become superior education pioneers in the digital era.

\section{AKNOWLEDGEMENT}

The author is grateful to The HKBP Nommensen University Medan for the supports and the effort to the lecturers to be more active to encourage the research competence.

\section{REFERENCES}

Adijaya, N. (2018). Persepsi Mahasiswa dalam Pembelajaran Online**Pengembangan teori dari penelitian berjudul "persepsi mahasiswa terhadap materi ajar pada pembelajaran online" yang telah dipublikasi di Jurnal Eduscience Vol. 3/1. Wanastra: Jurnal Bahasa Dan Sastra, 10(2), 105-110. https://doi.org/10.31294/w.v10i2.3931

Alqahtani, A. Y., \& Rajkhan, A. A. (2020). E-learning critical success factors during the covid-19 pandemic: A comprehensive analysis of e-learning managerial perspectives. Education Sciences, 10(9), 1-16. https://doi.org/10.3390/educsci10090216

Baldry Paul, J., A. T. (2008). Applications of Multimodal Concordances. Hermes: Journal of Language and Communication Studies, 41(41), 11-42.

Fang, X. I. E. (2015). A Study of College English Listening and Speaking Teaching on the Basis of Multimodal Theory \& SPEAKING COURSE IN COLLEGE. 10(6), 93-95. https://doi.org/10.3968/7148

Firmansyah, M. B. (2018). Multimodal Conception in Learning. ISLLAC: Journal of Intensive Studies on Language, Literature, Art, and Culture, 2(1), 40-44. https://doi.org/10.17977/um006v2i12018p040

Fjørtoft, H. (2020). Multimodal digital classroom assessments. Computers and Education, 152(September 2019), 1-11. https://doi.org/10.1016/j.compedu.2020.103892

Hidayah, R., Susiani, T. S., \& Salimi, M. (2019). Optimizing Multimodal Literacy in Elementary School Learning. 2(Snip), 339-344.

Jauhara, D., Emilia, E., \& Lukmana, I. (2018). Re-contextualising 'Greeting ': A multimodal analysis in an EFL Textbook. 1(1), 15-24.

Julinar, J. (2019). Teachers ' Perception towards the Use of Multimodality in Teaching Reading. 254(Conaplin 2018), 374-379. 
4023 Students' Perception toward English Speaking Motivation during Online Learning System through Multimodal Approach - Usman Sidabutar

DOI: https://doi.org/10.31004/edukatif.v3i6.1390

Kang, J. (2020). Speaking and Writing Connections in L2 : The Roles of Multimodal Teaching and Learning. 263-286.

Laadem, M., \& Mallahi, H. (2020). Multimodal Pedagogies in Teaching English for Specific Purposes in Higher Education: Perceptions, Challenges and Strategies. International Journal on Studies in Education, 1(1), 33-38. https://doi.org/10.46328/ijonse.3

Lee, H. C. (2014). Using an arts-integrated multimodal approach to promote English learning: A case study of two Taiwanese junior college students. English Teaching, 13(2), 55-75.

Lim, F. V. (2018). Developing a systemic functional approach to teach multimodal literacy.

Magnusson, P., \& Godhe, A. (2019). Multimodality in Language Education - Implications for Teaching. 11, $127-137$.

Martínez Lirola, M. (2020). Multimodal Teaching Proposal in an English as A Foreign Language Subject. ASIAN TEFL Journal of Language Teaching and Applied Linguistics, 5(1). https://doi.org/10.21462/asiantefl.v5i1.112

Nashir, M., \& Laili, R. N. (2021). English Teachers' Perception toward the Switch from Offline to Online Teaching during lockdown in the Midst of Covid-19 Outbreak. Edukatif: Jurnal Ilmu Pendidikan, 3(2), 250-260. https://doi.org/10.31004/edukatif.v3i2.287

Panyajamorn, T., Suanmali, S., Kohda, Y., Chongphaisal, P., \& Supnithi, T. (2018). Effectiveness of ELearning Design in Thai Public Schools. Malaysian Journal of Learning and Instruction, 15(1), 1-34.

Pratiwi, N. (2021). EDUKATIF : JURNAL ILMU PENDIDIKAN Pengaruh Model Pembelajaran Picture And Picture terhadap Kemampuan Berpikir Kreatif Siswa di Sekolah Dasar. 3(6), 3697-3703.

Putriani, J. D. (2021). Penerapan Pendidikan Indonesia di Era Revolusi Industri 4 . 0. Edukatif: Jurnal Ilmu Pendidikan, 3(3), 831-838.

Reyes-Torres, A., \& Raga, M. P. (2020). Multimodal approach to foster the multiliteracies pedagogy in the teaching of EFL through picturebooks: The snow lion. Atlantis, 42(1), 94-119.

https://doi.org/10.28914/Atlantis-2020-42.1.06

Ruiz-Madrid, N., \& Valeiras-Jurado, J. (2020). Developing multimodal communicative competence in emerging academic and professional genres. International Journal of English Studies, 20(1), 27-50. https://doi.org/10.6018/ijes.401481

Sankey, M. D. (2006). A neomillennial learning approach: Helping non traditional learners studying at a distance. International Journal of Education and Development Using Information and Communication Technology, 2(4), 82-99.

Sewell, W. C., \& Denton, S. (2011). Multimodal literacies in the secondary English classroom. English Journal, 100(5), 61-65.

Song, J. (2018). A Case Study on Multimodality Teaching in a College English Listening and Speaking Course. International Journal on Studies in English Language and Literature, 6(3), 1-4. https://doi.org/10.20431/2347-3134.0603001

Sullivan, F. R. (2018). Multimodal Learning. Creativity, Technology, and Learning, 96-112. https://doi.org/10.4324/9781315765143-8

Suryana, I., Hidantikarnillah, V., \& Ikmi Nur Oktavianti. (2020). Enhancing Students' English Speaking Skills through Web-Based Teaching. Eduvelop, 3(2), 90-104.

https://doi.org/10.31605/eduvelop.v3i2.601

Tampubolon sahlan, Usman, S., \& Srisofian, S. (2018). The Effect of English Laboratory Use in Speaking Ability. International Journal of Research and Review, 5(9), 177-183. 
4024 Students' Perception toward English Speaking Motivation during Online Learning System through Multimodal Approach - Usman Sidabutar

DOI: https://doi.org/10.31004/edukatif.v3i6.1390

Twiner, A., Littleton, K., Whitelock, D., \& Coffin, C. (2021). Combining sociocultural discourse analysis and multimodal analysis to explore teachers' and pupils' meaning making. Learning, Culture and Social Interaction, 30(PA), 100520. https://doi.org/10.1016/j.lcsi.2021.100520

Westberg, G. (2021). Affect as a multimodal practice. March, 19-38. https://doi.org/10.1177/2634979521992734

Xing, Y. (2019). Business English Listening and Speaking Teaching under Multimodal Conditions. Icetem, 1186-1189. https://doi.org/10.25236/icetem.2019.252

YANG, M.-H., \& TAO, J.-H. (2019). Data fusion methods in multimodal human computer dialog. Virtual Reality \& Intelligent Hardware, 1(1), 21-38. https://doi.org/10.3724/sp.j.2096-5796.2018.0010

Yusnimar, Y., Br Surbakti, E., \& Isa, I. (2020). Multimodal Analysis in Developing EFL Students' ESP Listening Skill in Civil Engineering. https://doi.org/10.4108/eai.15-11-2019.2296300

Yusriati, \& Hasibuan, S. H. (2019). Journal of English Education and Teaching. 3(2), 230-248. 